\title{
ANALISIS PENETAPAN MARGIN PADA PEMBIAYAAN MURABAHAH (STUDI KASUS PADA BPRS RAHMANIA DANA SEJAHTERA KABUPATEN BIREUEN)
}

\author{
Muhammad Ferdy Joely ${ }^{1}$, Ridwan ${ }^{* 2}$ \\ ${ }^{1,2}$ Program Studi Akuntansi Fakultas Ekonomi dan Bisnis Universitas Syiah Kuala \\ e-mail: ferdyjoe99@gmail.com ${ }^{1}$, ridwan.ibrahim@ unsyiah.ac.id ${ }^{2}$
}

\section{* Corresponding Author}

\begin{abstract}
Abstrak
Margin is the seller's rights agreed between the seller and the buyer. The profit margin is only found in the sale and purchase agreement. The percentage of profit obtained is an agreement between the seller and the buyer. So far, the $B P R S$ in general still has difficulty in adjusting the determination of the margin, because if the BPRS sets the margin in accordance with applicable BI regulations, it will burden the BPRS because there are differences between customers, products and third party funds from the BPRS and Islamic commercial banks. This study aims to determine the determination of margins in murabaha financing at BPRS Rahmania Prosperous Bireuen Regency. This study uses descriptive qualitative methods, data collection techniques in research conducted interviews, observations, and documentation conducted directly with the SRB manager Rahmania Dana Sejahtera Bireuen Regency. This research resulted in the procedure for determining the murabaha margin at the BPRS.
\end{abstract}

Keywords: Pembiayaan Murabahah, Margin Keuntungan, Penetapan Margin, Margin Murabahah

\section{Pendahuluan}

Suatu organisasi keuangan yang tujuan operasinya mengacu pada prinsip-prinsip syariah yang wajib terhindar dari riba, gharar, maisir dan akad yang batil merupakan pengertian dari Lembaga Keuangan Syariah (LKS). Target utama dari berdirinya LKS ialah agar dapat memenuhi perintah Allah mengenai hal ekonomi dan muamalah dan melepaskan umat muslim dari aktifitas yang diharamkan oleh Islam. Menurut Dewan Syariah Nasional (DSN), suatu organisasi finansial yang menerbitkan produk-produk syariah dan telah menerima izin operasional sebagai LKS merupakan definisi dari LKS. LKS dapat dibagi menjadi dua, lembaga keuangan bank, dan lembaga keuangan non-bank. Lembaga keuangan non-bank ada dari lembaga-lembaga keuangan yang bertugas dan kegiatan utamanya beda dengan bank, misalnya: asuransi, dana pensiun, pegadaian, leasing.

Pengertian ini menjelaskan bahwa LKS dalam mengeluarkan sebuah produk harus memenuhi dua elemen utama yakni; unsur keselaraasan dengan prinsip syariat Islam dan unsul legalitas operasional dari DSN.

LKS berdasarkan lembaga keuangan bank dibagi menjadi 2, Bank Umum Syariah (BUS) dan
Bank Perkreditan Rakyat Syariah (BPRS). BUS adalah bank yang menyediakan jasa seperti lantas pembayaran. BUS mudah ditemukan dan mempunyai cabang hampir di seluruh Indonesia sehingga tidak aneh lagi kalau bank umum syariah bisa mempunyai banyak nasabah di setiap kota yang ada di Indonesia.

Tidak ada system bunga dalam system perbankan syariah, maka orang bertanya-tanya dari manakah bank dan lembaga pembiayaan Syariah menerima untung melalui kegiatan pembiayaan yang diberikannya, contoh yang dapat diambil jika anda mempunyai keinginan membeli motor atau mobil dan meminta sokongan biaya dari Bank atau Pembiayaan syariah seperti BPRS tidak ada bunga yang dibebankan atas anda selain margin, karna sifat pinjaman tersebut sebenarnya pembiayaan, maka Bank atau perusahaan pembiayaan tersebut memilik peran sebagai penjual dan nasabah sebagai pembeli. maka wajarlah dari kegiatan jual beli tersebut bank atau perusahaan pembiayaan tersebut mempunyai harapan untuk memperoleh untuk dari selisih harga jual dan harga beli (margin/laba).

Persentase yang ditetapkan per tahun diartikan sebagai margin. Maka, jika margin dihitung perhari, jumlah hari didalam satu tahun diakui 360 hari dan 
apabila margin dihitung perbulan, setahun diakui 12 bulan. Secara umum, nasabah pembiayaan membayar secara diangsur. Penagihan yang muncul dari aktifitas jual beli dan atau sewa berdasar dengan akad murabahah, salam, istishna' dan atau ijarah dianggap sebagai piutang. Besar kecilnya piutang bergantung pada plafon pembiayaan, yaitu jumlah pembiayaan (harga beli ditambah harga pokok) yang tercatat pada perjanjian pembiayaan.

Margin adalah hak penjual yang telah disepakati antara penjual dan pembeli. Margin keuntungan hanya terdapat dalam akad jual beli. Persentase keuntungan yang didapatkan merupakan kesepakatan antara penjual dan pembeli. Besarnya margin keuntungan tidak akan bertambah, tidak seperti bunga yang sifatnya fluktuatif, margin keuntungan bersifat sama dengan sepakatnya seller dan buyer di awal akad.

Pendapatan Bank umum syariah di dapat dari margin dari produk yang dipasarkan. Margin setiap bank umum syariah berbeda-beda, tergantung berapa jumlah dana pihak ketiga yang diperoleh. Jika, suatu bank umum syariah mempunyai dana pihak ketiga yang banyak maka margin yang diperoleh antara nasabah dan bank akan besar, hal ini disebabkan karena bank bisa leluasa mengatur dananya untuk investasi. Margin juga sisebut seabagai alat ukur dari mampunya suatu lembaga keuangan untuk mengupayakan keuntungan bersih. Hasil yang diperoleh dapat dibandingkan diantara penjualan dan laba. Perhitungan margin sangat krusial karna penentuan langkah ke depan bagi sebuah lembaga keuangan, terutama untuk menentukan strategi penjualan dan penetapan harga.

BPRS adalah lembaga keuangan syariah yang kedua setelah bank umum syariah. BPRS merupakan suatu lembaga keuangan bank syariah, dan cara kerjanya berdasarkan pada prinsip syariah atau muamalah Islam. Bank Perkreditan Rakyat Syariah berdiri sesuai dengan UU No. 7 Tahun 1992 tentang Perbankan dan Perturan Pemerintah (PP) No. 72 Tahun 1992 tentang Bank berdasarkan Prinsip Bagi Hasil.

Berdirinya BPRS terkait erat dengan pengaruh adanya lembaga keuangan yang disebut diatas. Lebih jelasnya keberadaan lembaga keuangan tersebut dijelaskan dengan munculnya ide untuk membangun bank syariah pada di skala nasional. Indikator yang menjadi basic pada penetapan tingkat margin keuntungan murabahah pada bank BPRS hampir sama dengan BUS, yang mana berdasarkan jumlah tabungan nasabah atau jumlah dana pihak ketiga akan tetapi BPRS tidak memiliki jumlah nasabah dan dana pihak ketiga yang banyak seperti bank umum syariah. Begitu halnya yang berlaku pada Bank BPRS Rahmania Dana Sejahtera, yang mana tingkat pengukuran disebut juga jadi basic dalam menetapkan margin murabahah.

Portal berita online Okezone.com (2016) mengeluarkan berita yang dimana Bank Indonesia (BI) mengharapkan seluruh BPR dan BPRS di Indonesia menyesuaikan suku bunga acuan/margin yang diberlakukan oleh BI. Namun hal ini nyatanya akan memberatkan BPRS dalam beroperasi dikarenakan BPRS memiliki jumlah nasabah yang lebih sedikit daripada bank umum syariah. Sumber dana BPRS juga berasal dari Bank umum syariah sehingga wajar ketika margin yang diperoleh sedikit berbeda dengan bank umum syariah karena ada perbedaan antara nasabah, produk dan dana pihak ketiga dari pihak BPRS dan bank umum syariah. Ketua Perhimpunan BPR Indonesia (Perbarindo) Ascar Setiyono mengatakan jika BPRS menurunkan tingkat margin yang seperti Bank Umum lainnya hal ini akan memberatkan BPRS dalam hal operasional yang terdapat beberapa faktor yang nantinya akan membuat BPRS semakin sulit eksis di perbankan Nasional. Kebijakan BI untuk menyesuaikan margin juga berdampak pada BPRS Rahmania Dana Sejahtera yang berdiri pada tahun 2010 sehingga BPRS harus berulang kali merubah tingkat margin-nya tersebut.

Pendirian BPRS Rahmania Dana Sejahtera, dimulai operasionalnya pada tanggal 28 April 2010, dengan pedoman UU sesuai dengan konsep perbankan di Indonesia terutama dalam rangka ikut mengembangkan dan memberikan alternatif kepada masyarakat untuk menyimpan dananya dengan aman, dan memberikan solusi pembiayaan terutama lembaga keuangan yang mampu menyentuh masyarakat kecil dengan konsep syariah yang benar-benar islami. Setelah selesainya beberapa peraturan/SOP perusahaan maka sejak bulan Juli 2010 PT. BPRS Rahmania Dana Sejahtera mulai melakukan aktivitas marketing tidak saja dalam meningkatkan sumber dana pihak ketiga (DPK) seperti tabungan dan deposito akan tetapi juga dalam penyaluran dana untuk pembiayaan yang tentu saja dilakukan dengan prinsip-prinsip prudent banking. 
Peneliti telah melakukan observasi awal pada beberapa BPRS yang ada di Kabupaten Bireuen. Dari observasi yang telah dilakukan, peneliti mendapatkan informasi bahwa BPRS Rahmania Dana Sejahtera merupakan BPRS yang tepat untuk dijadikan objek dalam penelitian ini, dikarenakan BPRS Rahmania Dana Sejahtera ini telah dikenal luas oleh masyarakat di Kabupaten Bireuen, dan mudah untuk memperoleh data yang dibutuhkan untuk penelitian.

\section{Kajian Pustaka dan Kerangka Pemikiran Pembiayaan}

Sesuai dengan UU No. 10 Tahun 1998 tentang Perbankan Bab 1 pasal 1 No. 12 bahwa pembiaayaan sesuai dengan prrinsip syaariah ialah "penyediaan dana atau tagihan yang dapat disamakan berdasarkan persetujuan atau kesepakatan antara bank dan pihak lain yang mewajibkan pihak yang membiayai untuk mengembalikan uang atau tagihan tersebut setelah jangka waktu tertentu dengan imbalan atau bagi hasil sesuai dengan kesepakatan".

\section{Murabahah}

Menurut Antonio (2010:12), jual beli barang dengan harga awal dan ada penambahan laba yang disesuaikan merupakan definisi dari murabahah. Dalam ba'i al-murabahah, penjual harus menyatakan kepada pembeli harga produk yang diperoleh dan ditentukan penambahan harganya sebagai keuntungan. Menurut Muhamad, "perjanjian jual beli diantara bank dan nasabah di mana bank syariah membeli barang yang dibutuhkan oleh nasabah dan kemudian dijual kepada nasabah sesuai dengan harga yang diperoleh ditambah keuntungan yang diakadkan antar bank syariah dan nasabah adalah definisiki dari murabahah."

\section{Landasan Hukum Pembiayaan Murabahah}

\section{a. Al-Qur'an}

Firman Allah QS An-Nisa' Ayat : 29

Artinya: "Hai orang-orang yang beriman, janganlah kamu saling memakan harta sesamamu dengan jalan yang batil, kecuali dengan jalan perniagaan yang berlaku dengan suka samasuka di antara kamu. dan janganlah kamu membunuh dirimu; Sesungguhnya Allah adalah Maha Penyayang kepadamu" (An-Nisa: 29) b. Al-Hadist

Dari Abu Sa"id Al-Khudri, Nabi Muhammad SAW bersabda, "Sesungguhnya jual beli itu harus dilakukan suka sama suka." (HR. al- Baihaqi dan Ibnu Majah dan dinilai shahih oleh Ibnu Hibban).

c. Fatwa DSN-MUI

Pembiayaan murabahah telah diatur dalam Fattwa DSN No. 04/DSN- MUI/IV/2000. Dalam fatwa tersebut disebutkan ketentuan umum mengenai murabahah.

\section{Manfaat dan Resiko Pembiayaan Murabahah}

Terdapat berbagai manfaat dari transaksi bai' al-murabahah, dan beberapa risiko yang harus diantisipasi. Banyak manfaat yang diperoleh oleh bank syariah dari ba'i al-murabahah, yaitu salah satunya terdapat keuntungan yang muncul dari selisih harga beli dari seller dengan harga dijual kepada nasabah. Sistem bai' al- murabahah juga sangat mudah. Hal tersebut memudahkan pengurusan di bank syariah.

\section{"Mekanisme Penetapan Margin Keuntungan Murabahah Pada Bank Syariah"}

Untuk menjaga tingkat kinerja keuangan bank, tidak dapat dilepaskan daari Asset Liability Managementt Committee yang berperan sebaagai pengambilkeputusan untuuk menentuukan tingkat bunga lending dan funding bank yang terkait. Hal tersebut dilakukan oleh ALCO. Salah satu fungsi dari ALCO yaitu untuk meningkatkan portofolio neraca bank serta memaksimalkan keuntungan (Nugrohowati, 2015).

Menentukan bermacam-macam keputusan di dalam aplikasi atau pengguna dana, menilai kewajiban bank, dan membuat kebijaksanaan dan memonitor posisi modal bank merupakan peranan dari ALCO. Semua bank mempunyai ALCO karena untuk menentukan bermacam-macam kebijaksanaan di dalam kegunaan dana dan memberi batasan besarnya kredit yang dapat disalurkan.

Aturan basic penetapaan keuntungan murabahah pada Bank Syariah berdasarkan pada referensi margiin yang di tetapkan dalamrapat ALCO bank syariah (Karim, 2011).

Tim ALCO memiliki akses terhadap liabilitas dan strategi pemberian harga terhadap pinjaman, mengupayakan praktik menguasai dana dan memilih agar mengalokasikan pinjamaan, memantau spreed, 
distribusi aset/kewajiban, jangka waktu, bagaimanaa deaaling dengan secondaary reserve untuk aktifitas pasar uang, mereview varian anggaraan dan yang terpenting ialah menyusuun aaction plant berdasar seba terjadi nya varian.

\section{Bank Pembiayaan Rakyat Syariah}

Berdasarkan UU 21 tahun 2008 tentang Perbankan Syariah Bab 1 Pasal 1, Bank Syari'ah merupakan apapun yang bersangkutan mengenai perbankan Syari'ah dan Unit Syari'ah, mencakuup kelembagaaan, kegiaatan usaaha, serta tatacara-proses syari'ah dan menuruut jenissnya atas perbankan Umum Syari'ah dan pembiayaaan syari'ah. Salah satu bentuk lembaga keuangan syari'ah adalah BPRS. Bank Syari'ah yang dalam aktifitasnya tidak memberi jasa dalam lantas pembayaran ialah pengertian dari BPRS (Suip et.al, 2014).

\section{Metode Penelitian \\ Desain Penelitian}

Menurut Sekaran \& Bougie (2013:95) design penelitian merupakan bagan (blueprint) agar pengumpulan, pengukuran, dan analisis data sesuai pada permasalahan studi penelitian. Desain dalam penelitian ini menggunakan metpen kualitatif. Jenis penelitian yang dipakai pada penelitian ini adalah metpen deskripsi kualitatif. Metode deskripsi mnurut Sanusi (2014:13) ialah "desain penelitian yang disusun dalam rangka memberikan gambaran secara sistematis tentang informasi ilmiah yang berasal dari subjek atau objek penelitian". Sanusi $(2014 ; 13)$ juga mengatakan bahwa "penelitian deskriptif berfokus kepada penjelasan sistematis tentang fakta yang diperoleh saat penelitian dilakukan".

\section{Sumber dan Teknik Pengumpulan Data}

Sumber data pada penelitian ini adalah data primer dan data sekunder. Data primer berupa wawancara dan observasi dan data sekunder berupa data dokumentasi, seperti laporan keuangan. Teknik pengumpulan data yang digunakan dalam penelitian ini dengan dua cara, yaitu penelitian langsung ke lapangan dan studi kepustakaan.

\section{Teknik Analisis Data}

Penelitian ini adalah penelitian deskriptif yang bersifat paparan dari hasil wawancara dan studi dokumentasi. Data yang diperoleh akan dianalisa dengan cara kualitatif serta dipaparkan dalam bentuk deskripsi. Metode ini tidak membutuhkan hipotesis, namun dibutuhkan kerangka pemecah masalah untuk membantu peneliti dalam melakukan penelitian.

Moleong (2011:4) menyebutkan "analisis data adalah proses mengatur, urutan data, mengorganisasikannya ke dalam suatu pola, kategori dan uraian dasar. Definisi tersebut memberikan gambaran tentang betapa pentingnya kedudukan analisis data dilihat dari segi tujuan penelitian. Prinsip pokok penelitian kualitatif adalah menemukan teori dari data".

"Teknik analisis data yang digunakan dalam penelitian ini adalah menggunakan langkah-langkah seperti yang dikemukan oleh Bungin (2013:70) sebagai berikut :

1) Pengumpulan Data

Pengumpulan data merupakan bagian integral dari kegiatan analisis data. Kegiatan pengumpulan data pada penelitian ini adalah dengan menggunakan wawancara dengan admin Pembiayaan di BPRS Rahmania Dana Sejahtera dan studi dokumentasi tentang margin Murabahah.

2) Reduksi Data

Reduksi data, diartikan sebagai proses pemilihan, pemusatan perhatian pada penyerderhanaan dan transformasi data kasar yang muncul dari catatan-catatan tertulis dilapangan. Reduksi dilakukan sejak pengumpulan data dimulai dengan membuat ringkasan, menelusur data, menulis memo dan sebagainya dengan maksud menyisihkan data/informasi yang tidak relevan. Reduksi yang dilakukan adalah mengenai penetapan margin pada Pembiayaan Murabahah.

3) Display Data

Display data adalah pendeskripsian sekumpulan informasi tersusun yang memberikan kemungkinan adanya penarikan kesimpulan dan pengambilan tindakan. Dengan penyajian data, peneliti akan membahas bagaimana penetapan margin pada pembiayaan murabahah di BPRS Rahmania Dana Sejahtera.

Langkah-langkah yang perlu dilakukan dalam menganalisis data pada metode ini adalah: 
1) Mengumpulkan data-data yang berkaitan dengan masalah yang akan diteliti pada BPRS Rahmania Dana Sejahtera.

2) Mengidentifikasi bagaimana analisis penetapan margin pada pembiayaan murabahah di BPRS Rahmania Dana Sejahtera.

3) Menganalisis pelaksanaan akad murabahah pada pembiayaan perumahan di BPRS Rahmania Dana Sejahtera apa telah sesuai dengan aturan syariat yang berlaku."

\section{Hasil Penelitian dan Pembahasan Gambaran Umum Penelitian}

Penelitian ini dilakukan pada perusahaan yang bergerak di bidang perbankan (keuangan) yaitu BPRS Rahmania Dana Sejahtera Kabupaten Bireuen. Penelitian ini memilik tujuan agar melihat penerapan keuntungan dalam peembiayaan Murahabah pada BPRS Rahmania Dana Sejahtera.

\section{Sejarah BPRS Rahmania Dana Sejahtera}

Pendirian Bank Pembiayaan Rakyat Syariah (BPRS) Rahmania Dana Sejahtera, dimulai operasionalnya pada tanggal 28 April 2010, dengan pedoman UU sesuai dengan konsep perbankan di Indonesia terutama dalam rangka ikut mengembangkan dan memberikan alternatif kepada masyarakat untuk menyimpan dananya dengan aman, dan memberikan solusi pembiayaan terutama lembaga keuangan yang mampu menyentuh masyarakat kecil dengan konsep syariah yang benar-benar islami.

\section{Hasil Penelitian}

\section{Pembiayaan Murahabah pada BPRS Rahmania Dana Sejahtera}

Menurut fatwa DSN MUI memberikan Ketentuan Umum Murahabah dalam Bank Syariah, yaitu:

a. Penggunaan transaksi Murahabah yang tidak
riba'.
b. Item yang dijualbelikan tak haram menurut
syari'ah.
c. perbankan membelibarang dengan sah dan tidak
riba'.
d. perbankan mengutarakan apapun mengenai
pembelianpertama.
e. Perbankan lalu menjualbarang tersebut pada pemesann dengan hargajual seharga harga beli ditambah untungnya. Pada kaitan ini, perbankan harus transparan tentang harga pokok barang terhadap pemesan dan mengenai biaya yang dibutuhkan.

f. Pemesan membayaar hargabarang yang telah disepakati tersebut dalam jangkawaktu yang sudah disepakatii.

g. Unuk mencegahterjadinya penyalahgunaan atau kerusakan perjanjian tersebut, pihakbank dapat melakukan janji khusus dgn pemesan.

h. Apakah perbankan ingin mewakili pada pemesan unuk membelibarang dari kelompok yang lain, transaksi jualbeli Murahabah antara perbankan dgn pemesan harusdilakukan setelah barang yang diperjual belikan secara prinsip, jadi milik perbankan.

i. Pembiayaan Murahabah telah diparaktikkan oleh BPRS Rahmania Dana Sejahtera dalam rangka pembelian barang. Sebagaimana proses munculnya wakalah disebabkan karena kelemahan bank juga tidak bisa menyediakan ready stock barangnya. BPRS Rahmania Dana Sejahtera dalam melaksanakan pembiayaan Murahabah adalah Nasabah harus menentukan jenis barang yang akan dibeli, Bank mewakilkan/memberikan kuasa pada nasabah untuk memilih sendiri, ketika sudah cocok Bank melakukan akad Murahabah

Menurut uraian di atas maka dapat dilihat bahwa Pelaksanaan pembiayaan Murahabah pada KPRS di BPRS Rahmania Dana Sejahtera menggunakan wakaalah. Praktik tersebut di sini telah sesuai fatwa DSN MUI No. 04/DSN-MUI/IV/2000 butir 9 tentang penguasaan barang yang secara prinsip harus menjadi milik BPRS Rahmania Dana Sejahtera dan semua hal yang mengatur tentang Murahabah.

Dalam hal pembayaran angsuran, DSN MUI tidak mengatur tata cara pembayaran angsuran dalam Murahabah hanya saja fatwa DSN MUI menetapkan beberapa ketentuan khusus mengenai diberlakukannya potongan pelunasan dalam Murahabah.

\section{Pembahasan}

\section{Penerapan Margin dalam Pembiayaan Murahabah pada BPRS Rahmania Dana Sejahtera}

Margin yang terdapat pada pembiayaan murabahah ditentukan berdasarkan rekomendasi dan 
saran dari hasil rapat. Artinya nilai margin dari hasil referensi ini menjadi standar acuan minimal untuk penetapan margin murabahah di BPRS Rahmania Dana Sejahtera.

Rapat penetapan margin dilakukan pada Tanggal 13 Januari 2018 yang dihadiri oleh Dewan Komisaris dan Direksi BPRS Rahmania Dana Sejahtera. Rapat ini bersifat memorandum, dimana hanya mengoreksi margin yang telah ditetapkan sebelumnya. Kebijakan ini efektif mulai Tanggal 1 Feburari 2018 dan akan berlaku sampai batas waktu yang tidak ditentukan. Khusus murabahah ini, besaran bagi hasil pihak ketiga menjadi acuan utama dalam penentuan margin. Berikut adalah hasil wawancara dengan Manajer di BPRS Rahmania Dana Sejahtera: "Dalam prakteknya penentuan margin murabahah dilakukan setelah diketahui besaran bagi hasil pada pihak ketiga".

Besarnya prosentase dibedakan berdasarkan pada besarnya plafon pembiayaan yang diajukan nasabah dengan rincian sebagai berikut:

\section{Tabel 4.1}

Penetapan Margin

\begin{tabular}{|c|c|}
\hline Limit & Margin \\
\hline $1-5$ juta & $22 \%$ \\
\hline $6-10$ juta & $20 \%$ \\
\hline $11-50$ juta & $18 \%$ \\
\hline $51-75$ juta & $17 \%$ \\
\hline $76-100$ juta & $16 \%$ \\
\hline$>100$ juta & $15 \%$ \\
\hline
\end{tabular}

Berdasarkan Tabel 4.1 dapat dijelaskan bahwa penetapan besaran margin pada BPRS Rahmania Dana Sejahtera dibagi ke dalam 6 kategori, dimana semakin besar harga barang yang akan dibeli oleh nasabah, maka margin yang ditawarkan akan semakin kecil.

\section{Kesimpulan}

Berdasarkan hasil penelitian dan analisis data yang telah dijelaskan sebelumnya, maka dapat disimpulkan beberapa hal sebagai berikut :

1. Penentuan margin pada BPRS Rahmania Dana Sejahtera diterapkan dalam produk pembiayaan menggunakan akad murahabah, maka dapat disimpulkan sebagai berikut:

a. Keuntungan yang ada didalam pembiayaan murabahah ada penentuan sesuai dengan rekom dari hasil rapat. Maksudnya nilai keuntungan dari output referensi ini jadi standar acuan untuk menetapkan keuntungan murabahah pada BPRS Rahmania Dana Sejahtera. Khusus murabahah ini, besaran bagi hasil pihak ketiga menjadi acuan utama dalam penentuan margin.

b. Penentuan margin murabahah menggunakan acuan base lending rate.

c. Penetapan margin murabahah di BPRS Rahmania Dana Sejahtera juga ditentukan oleh faktor internal maupun eksternal lainnya. Seperti Dana pihak ketiga dan harga pasar.

\section{Saran}

Saran Akademis

1) Agar penelitian selanjutnya menambah/meneliti industri syariah lain, seperti BUS, UUS dan pegadaian syariah.

Saran Praktis

1. Bagi Nasabah, hasil penelitian ini dapat memberikan informasi dalam menentukan pilihan perbankan syariah

\section{Daftar Pustaka}

Antonio, MuhammadaSyafii.i2010. Bank Syariah dari Teori ke Praktik. Jakarta:Tazkiaa Cendekia.

Anwar, Sanusi. 2014. Metodologi Penelitian Bisnis. Jakarta: Salemba Empat.

Bungin, Burhan. 2013. Metode Penelitian Sosial \& Ekonomi: Format-format Kuantitatif dan Kualitatif untuk Studi Sosiologi, Kebijakan, Publik, Komunikasi, Manajemen, dan Pemasaran edisi Pertama. Jakarta: Kencana Prenada Media Group.

Moleong, L.J. 2011. Metodologi Penelitian Kualitatif Edisi Revisi. Bandung: PT Remaja Rosdakarya.

Republik Indonesia. Undang-Undang Republik Indonesia No. 10 tahun 1998 tentang Bank dengan Sistem Bagi Hasil sebagai Perubahan Undang-Undang No. 7 tahun 1992.

. Undang-Undang Republik Indonesia No. 10 tahun 1998 tentang Bank dengan Sistem Bagi Hasil sebagai Perubahan Undang-Undang No. 1 tahun 1992

Undang-Undang Republik Indonesia No.21 Tahun 2008 tentang Perbankan Syariah

Sekaran, Uma dan Roger Bougie. 2013. Research 
Methods for Business (A Skill Building Approach) Fifth Edition. United Kingdom: Wiley. 